FORTHCOMING MEETINGS

Earth Science Symposium on Offshore Eastern Canada, Camsell Hall, 588 Booth St., Ottawa, Ont.. February $22-24,1971$.

Monday Afternoon, February 22nd:

Session Chairmen - P.J. Hood, Exploration Geophysics Division, Geological Survey of Canada; and B.R. Pelletier, Bedford Institute

1. Regional Geology Eastern Canada Offshore - G.H. Austin and R.D. Howie (Austin Explorations)

2. The Continental Margin - M.J. Keen and C.E. Keen (Dalhousie University)

3. Tertiary and Late Mesozoic History of the Shelf Regions of the Eastern Canada Continental Margin - L. Smith (Queen's University)

4. The Canadian Atlantic Continental Margin - Paleography, Paleoclimatology and Seafloor Spreading - G.A. Bartlett (Queen's University)

5. Palaeomagnetism in Eastern Canada a Key for Reconstructing the Atlantic - E.R. Deutsh (Memorial University)

6. Paleolatitudes of Oilfields - Application to eastern Canada - J.L. Roy (Earth Physics Branch, Dept. of Energy, Mines \& Resources)

7. Geodynamics Project - C. Drake (Dartmouth,College, N.H.)

Tuesday Morning, February 23rd - Bay of Fundy and Scotian Shelf:

Session Chairmen - G.D. Hobson, Exploration Geophysics, Geological Survey of Canada; and B. D. Loncarevic, Bedford Institute

8. Nova Scotia, Morocco and Continentai Drift - P.E. Schenk (Dalhousie University)

9. Bedrock Geology of Scotian Shelf and Adjacent Areas - L.H. King (Bedford Institute)

10. Quaternary Sedimentation in the Bay of Fundy - D.J. Swift (old Dominion University), B.R. Pelletier, (Bedford Institute), A.K. Lyall (Smithsonian Institution), J.A. Miller (University of Texas)

11. Spill-over of Sediment from the Continental Shelf to the Slope and Rise off Nova Scotia D.J. Stanley et al. (Smithsonian)

12. Geological Structure Beneath the Bay of Fundy and the Continental Margin from Ocean Tide Loading - C. Beaumont (Dalhousie University)

13. Seismic Profiler and Magnetometer Results from Scotian Shelf and Adjacent Areas - G.W. Webb (University of Massachusetts)

14. Marine Seismic - W.H. Elias (Catalina)

15. Magnetic Surveys of the Scotian Shelf - P. MCGrath and P.J. Hood (Geological Survey of Canada)

16. The Sable Island Deep Test of the Scotian Shelf - D.H. Magnusson (Mobil Oil)

Tuesday Afternoon, February $23 \mathrm{rd}$ - Gulf of St. Lawrence:

Session Chairmen - W.H. Poole, Geological Survey of Canada; and P.J. Savage, Teledyne

17. Bedrock and Surficial Geology of the Northern Gulf of St. Lawrence as Interpreted from Continuous Seismic Reflection Profiles - J.M. Shearer (Geological Survey of Canada)

18. Marine Geology of the Gulf of St. Lawrence (1) Bedrock Geology; (2) Glacial \& Postglacial Geology - D.H. Loring (Fisheries Research Board)

19. Sedimentary Seismic Surveys, Gulf of St. Lawrence - G.D. Hobson and A. Overton (Geological Survey of Canada)

20. Gravity Measurements in the Gulf of St. Lawrence - R.T. Haworth (Bedford Institute), A.B. Watts and A.K. Goodacre (Earth Physics Branch)

21. Aeromagnetic surveys of the Gulf of St. Lawrence - P. McGrath and P.J. Hood (Geological Survey of Canada)

22. Geological and Geophysical Results Bearing upon the Structural History of the Flemish Cap Region - A.C. Grant (Bedford Institute)

23. Structural Implications of Gravity and Magnetic Anomalies over Eastern Notre Dame Bay, Newfoundland - H.G. Miller (University of British Columbia) and E.R. Deutsch (Memorial Univ.)

24. Hudson Geotraverse - B.D. Loncarevic (Bedford Institute)

25. Structure of the Great Bank of Newfoundland and the Flemish Cap - R.F. MacNab (Bedford Institute)

26. Orphan Knoll - A "Chip" off the North American "Plate" - A. Ruffman (Bedford Institute) and J. Van Hinte (Imperial)

Wednesday Morning, February 24th - Labrador Sea and Baffin Bay:

Session Chairmen - E.R. Deutsch, Memorial University; and N.J. McMillan, Tenneco

27. Results of JOIDES Drilling in the Labrador Sea - A. Ruffman (Bedford Institute) and J. Van Hinte (Imperial)

28. Spreading History of the Labrador Sea - M.A. Mayhew (New York University)

29. Geochemistry of Interstitial Waters from Baffin Bay Marine Sediments - G.M. Friedman et al (Rensselaer)

30. Distribution patterns of benthonic and planktonic Foraminifera in Baffin Bay - M.R. Gregory 
and C. Stehman (Dalhousie University)

31. Lateral and Vertical Variations in Sediments Characteristics Within Baffin Bay - S.R. Baker and G.M. Friedman (Rensselaer)

32. Bathymetric Observations along the East Coast of Baffin Island - O.H. L $\phi k$ kn (Inland Waters)

33. The Geological Setting of the West Greenland Basin - G. Henderson (Geological Survey of Green land)

Wednesday Afternoon, February 24th - Baffin Bay and Labrador Sea:

Session Chairmen - M.J. Keen, Dalhousie University; and D.I. Ross, Bedford Institute

34. Magnetic Properties of Rock Samples from the Baffin Bay Coast - L.G. Kristjansson and E.R. Deutsch (Memorial University)

35. Magnetic Basement Mapping in the Sedimentary Basins of Nugssuaq, West Greenland - P.V. Sharma (University of Copenhagen)

36. Low-level aeromagnetic surveys of the continental shelves bordering Baffin Bay and the Labrador Sea - P.J. Hood and M.E. Bower (Geological Survey of Canada)

37. Cretaceous - Lower Tertiary Rift Basin of Baffin Bay - Continental Drift without Sea-Floor Spreading - R. Martin (Rudolf Martin \& Associates Ltd.)

38. Geophysical and Geological Studies in Baffin Bay - R.D. Hyndman et al. (Dalhousie University) 39. Geophysical Studies on the Structure of Baffin Bay - D.L. Barrett et al. (Bedford Institute). 40. Icebergs: a New Problem for Offshore Oil Operations - J. Duval (Eastcan Exploration Itd.)

24 th International Geological Congress, Montreal, Quebec, Canada, August - September, 1972.

The following comments are from GEOCONG NEWS No. 2, August 1970 by C.G. Winder, University of Western Ontario, London, Canada. 6300 questionnaires received indicated the following chances of attendance: good - 3600; fair - 1800; slight - 900. More than 50,000 first circulars were sent out but many forms not received. To be included in the second circular, questionnaires must be completed and returned so that addresses can be stored in a computer's memory. Replies have come from 107 countries with 32 to hear from. The technical program has been organized in 17 sections and 6 symposia. Over 2,000 titles have been offered although only 750 will be presented.

1971 Joint Annual Meeting of the Geological Association of Canada and the Mineralogical Association of Canada, Laurentian University, Sudbury, Ont., May 13-15, 1971.

The program will feature three special sessions: (1) Sudbury Geology, with emphasis on evidence for and against an origin of the Sudbury Basin by meteorite impact - papers may be directed to Dr. J.V. Guy-Bray, International Nickel Company of Canada Limited, Copper Cliff, Ontario; (2) Huronian Stratigraphy and Sedimentation - papers to Dr. G. Young, Geology Department, University of Western Ontario, London, Ontario; (3) Sulphide - Silicate Systems - papers to Dr. S. Scott, Geology Department, University of Toronto, Toronto, Ontario. General papers under the regular divisions may be submitted to program chairman, J.C. Cowan, Falconbridge Nickel Mines Limited, Falconbridge, Ontario. Chairman of the organizing committee is Dr. D.H. Williamson and the secretary is Dr. J.F. Davies, both of Laurentian University, Sudbury, Ontario.

\section{REPORTS ON RECENT MEETINGS}

Central Canada University Geological Congress, Queen's University, Kingston, Ont., October 22-25, 1970.

The theme of the conference was "Geology of the 70's - the ocean decade". Transactions of the conference including the titles listed below will be published.

B.R. Pelletier - Canadian Marine Geology: A look at the past and into the 70's

A. McIntyre - Microorganisms as paleooceanographic indicators in the Atlantic ocean

S.J. Nelson - The Paleozic Ocean

J.T. Wilson - The life cycle of ocean basins - Key to the history of the earth's surface

J.W. Murray - Structure of the continental shelf off Vancouver Island, B.C.

B.D. Loncarevic - Marine Geology is Really Geophysics

K.K. Turekian - Geochemistry of the Atlantic Ocean Basin

R.L. Thomas - The Distribution and Geochemistry of Recent Sediments in Lake Ontario

D.R. Derry - Mineral Exploration in Canada and its relationship to past and present oceans

M.J. Colpitts - Ocean Technology - Man in and on the Ocean

D.W. Axford - petroleum in the Seas and on the Continental Shelves with particular reference to the opportunities in such areas in Canada 